\title{
Age, growth rate, and growth trajectory determined from otolith microstructure of southern bluefin tuna Thunnus maccoyii larvae
}

\author{
Greg P. Jenkins*, Tim L. O. Davis \\ CSIRO Division of Fisheries, Marine Laboratories, GPO Box 1538, Hobart, Tasmania 7001, Australia
}

\begin{abstract}
Otolith microstructure of larvae of southern bluefin tuna, Thunnus maccoyii (Castelnau, 1872), collected from the east Indian Ocean in January/February 1987 was examined using light and scanning electron microscopy. Daily formation was verified by examining the growth of the marginal increment on otoliths of larvae collected on 6 successive days. Most of the larvae sampled came from a single cohort which spawned over $2 \mathrm{~d}$. The daily progression of increment number for this cohort was further evidence that increments were formed daily. Larvae ranged from ca 7 to 18-d-old; the larval stage appeared to last ca $20 \mathrm{~d}$. Growth curves could not be fitted to plots of size-at-age due to a large variance in size-at-age and violation of assumptions for parametric tests. Back-calculation of individual growth trajectories was possible because growth of sagittae was exponential relative to body length, and there was a strong linear relationship between log otolith radius and standard length $\left(R^{2}=0.91\right)$. Growth trajectories of larvae were approximately linear, $\mathrm{R}^{2}$ ranging from 0.972 to 1.0 , with a median value of 0.996 . The distribution of individual growth rates was approximately normal, ranging from 0.20 to $0.47 \mathrm{~mm} \mathrm{~d}^{-1}$ and a mean of $0.32 \mathrm{~mm} \mathrm{~d}^{-1}$. Over the range examined, the growth of T. maccoyii larvae was relatively slow and linear, although the growth trajectories of oldest larvae exhibited a curvilinear increase in the days immediately preceding collection. The fast growth often attributed to young stages of tuna must occur in the late larval/early juvenile stage rather than the early larval stage of this species.
\end{abstract}

\section{INTRODUCTION}

The discovery of daily increments in otoliths (Pannella 1971) has made the interpretation of otolith microstructure a major tool for investigating the early life history of fishes. The presence of daily increments has now been verified for a wide variety of species (Jones 1986). The precision of estimates of age, growth, mortality and timing of life history events is greatly increased where daily increments can be utilised. While population growth rates can be determined from plots of size-at-age, a strong relationship between otolith-size and body-size makes it possible to determine the size at each day of life of an individual larva from the radius of each daily increment (Campana \& Neilson 1985, Mosegaard et al. 1988). Thus, the growth history of an individual is recorded in its otoliths. To

\footnotetext{
- Present address: Victorian Institute of Marine Sciences and Department of Zoology, University of Melbourne, Parkville, Victoria 3052, Australia
}

date there has been little detailed study of the day-today relationship between increment width and fish growth, and interpretation of growth from increment widths at a daily level of precision would not be advisable without information on this relationship (Campana $\&$ Neilson 1985). Even without this information, however, when otolith size and body size are strongly related, back-calculation provides a good estimate of the growth trajectory and growth rate averaged over the life of an individual larva.

The only known spawning area for southern bluefin tuna Thunnus maccoyii is off the northwest of Australia. Juveniles subsequently migrate around the southern coast of Australia, and when mature move off the Australian shelf and disperse throughout the Southern Ocean. The distribution is almost circumpolar between latitudes $30^{\circ}$ and $50^{\circ} \mathrm{S}$ (Shingu 1980). The population is fished by Australia, Japan, New Zealand and other countries at various stages of the life cycle; it is thought to be substantially overexploited, and the future of the population at present levels of exploitation is in doubt (Caton \& Majkowski 1987). But despite the 
importance of southern bluefin tuna, the age and growth characteristics of its larvae are unknown.

As part of a study on the reproduction and early life history of southern bluefin tuna, we have used otolith microstructure to examine the age and growth of larvae. In this paper we describe the otolith microstructure of Thunnus maccoyii larvae, validation of the daily periodicity of increment formation in otoliths, the age distribution of larvae in our samples, and the growth rates and growth trajectories of individual larvae backcalculated from daily increment widths.

\section{MATERIALS AND METHODS}

Sampling was carried out in January/February 1987 in the spawning grounds of Thunnus maccoyii (Castelnau, 1872) previously defined by Japanese surveys in the east Indian Ocean (Nishikawa et al. 1985). The sampling regime was primarily designed to examine the fine- to coarse-scale horizontal distribution of T. maccoyii larvae (T. L. O. Davis unpubl.). A concentration of $T$. maccoyii larvae was found at $16^{\circ} 30.2^{\prime} \mathrm{S}$, $115^{\circ} 50.4^{\prime} \mathrm{E}$, and a satellite-tracked buoy with parachute drogue set at $20 \mathrm{~m}$ depth immediately deployed. Fifty surface samples, each separated by $500 \mathrm{~m}$, were collected along a transect SW of the buoy (Fig. 1).

After the surface transect was completed, a series of random samples within a $20 \mathrm{~km}$ radius of the buoy were taken over $6 \mathrm{~d}$ (Fig.1). Surface water temperatures over this period ranged from 27.2 to $27.7^{\circ} \mathrm{C}$.

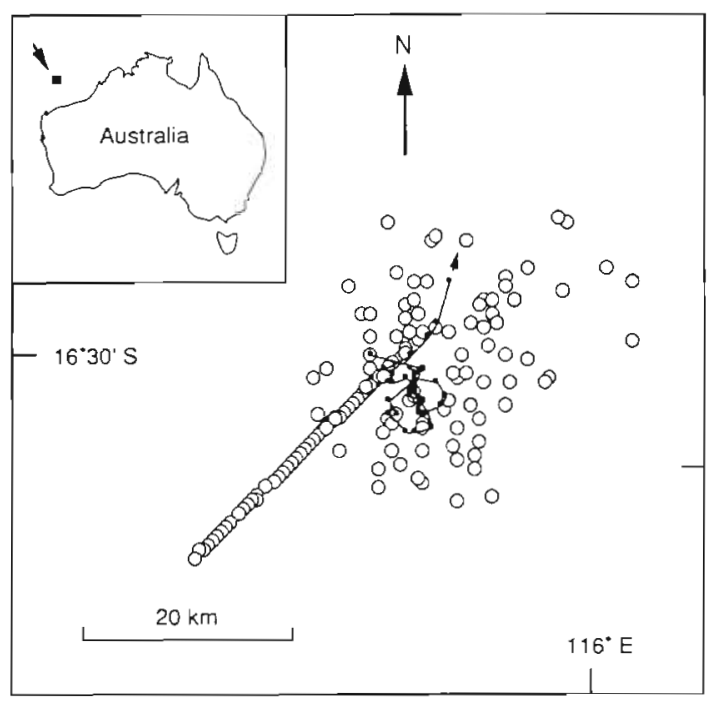

Fi.g. 1. Chart showing stations sampled for tuna larvae in the east Indian Ocean. Continuous line indicates track of satellitetracked drogue; arrow indicates direction of movement. Inset: location of sampling area relative to Australian coast
Approximately 12 day and 10 night samples were taken each $24 \mathrm{~h}$. Half of the stations were sampled with a $10 \mathrm{~min}$, double-oblique tow to the top of the thermocline, while the remaining stations were sampled with a combination of a $10 \mathrm{~min}$ surface tow and a 20 min double-oblique tow to the thermocline, with nets deployed concurrently. Only samples collected with oblique tows were used in this study.

All samples were collected with a $0.5 \mathrm{~mm}$ mesh cylinder-cone net attached to a $70 \mathrm{~cm}$ collar - equivalent to one side of an Ocean instruments $70 \mathrm{~cm}$ bongo net. Samples were preserved in $95 \%$ ethanol, which was replaced with fresh ethanol within $24 \mathrm{~h}$. Full descriptions of the net and sampling are given in Davis et al. (1989).

Tuna larvae were sorted from plankton samples in a rotatable sorting ring under a dissecting microscope with dark-field illumination. They were identified to species using, in the main, the criteria of Nishikawa (1985). Where more than 20 larvae occurred in a sample, a random subsample of 20 larvae was made. Standard length ( $\mathrm{SL}_{i}$ tip of the snout to tip of the notochord, or the hypural crease in post-flexion larvae) was measured under a dissecting microscope with an ocular micrometer. SL was not corrected to live length.

Specimens were placed in a drop of water on a microscope coverslip and their otoliths teased out with electrolytically-sharpened tungsten needles. The microscope was fitted with polarising filters which when crossed greatly increased otoliths visibility. Only sagittae and lapilli were present in the otic capsules of most larvae; asterisci were present in a few of the largest. Otoliths, which are semi-hemispherical in shape, were orientated with the flat side against the coverslip. Once they were air dry, a drop of Gurr's neutral mounting medium was placed on the coverslip and a microscope slide was lowered over it for permanent mounting. This technique ensured that otoliths were orientated squarely, with flat surface upwards, for optimal microscopic examination. Sufficient mounting medium was used to prevent the coverslip crushing the otolith when set and contracted. The gross morphology of otoliths was very similar to that described by Brothers et al. (1983) for Atlantic bluefin tuna Thunnus thynnus and the same focusing criteria was used.

Otoliths were viewed with a video system fitted to a compound microscope at a magnification of 920 or $2360 \times$. An H. E. C. 'Video coordinate digitiser' and an. Apple Macintosh microcomputer were used to digitise otolith counts and measurements with an electronic cursor. Specimens were examined double blind, and only specimens for which increment counts were identical for both left and right sagittae, and for successive readings, were accepted. Approximately $8 \%$ of specimens were rejected. 

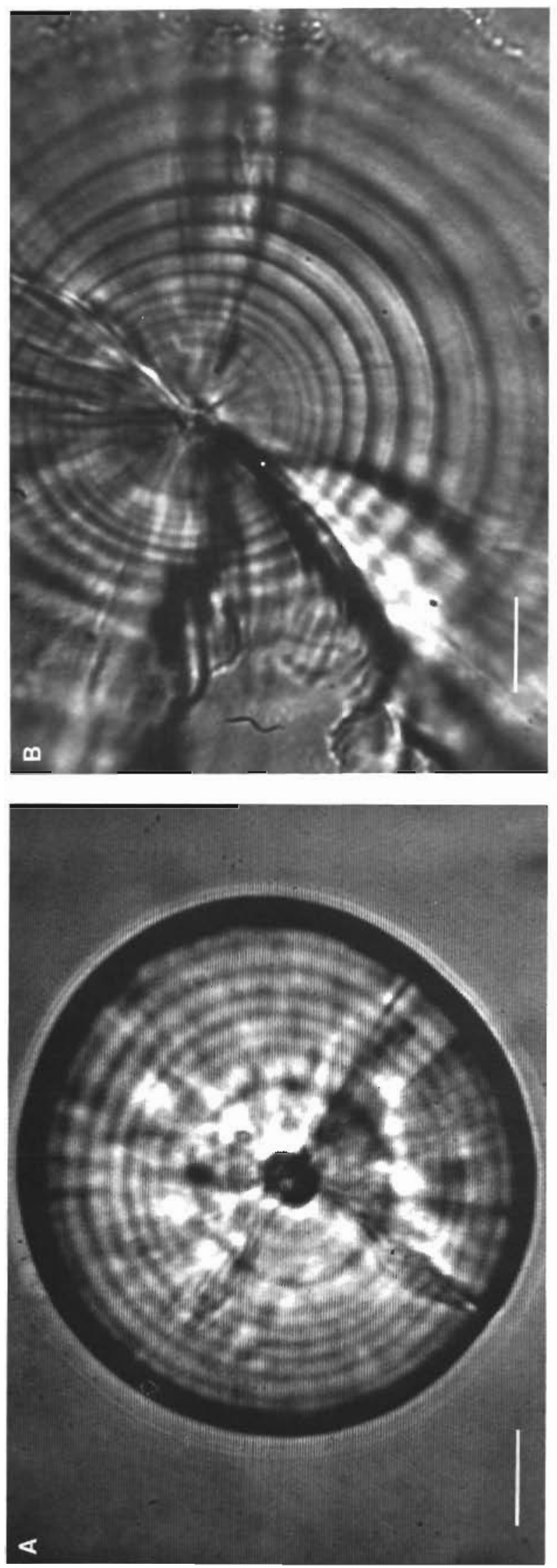

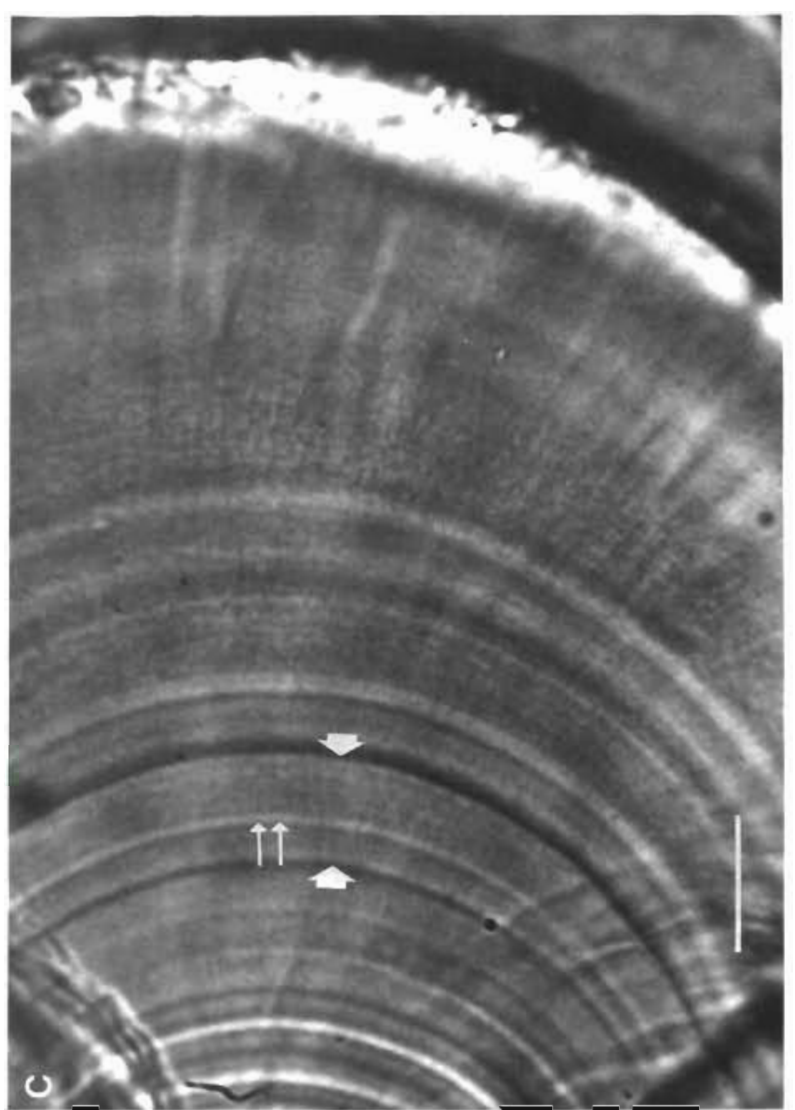

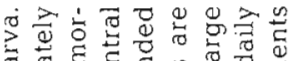

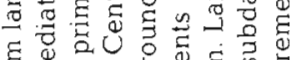
ह日,

ह

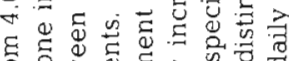

E

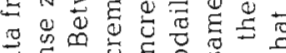
它安. is $>$ o

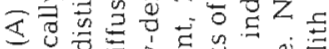
s.

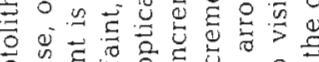
o

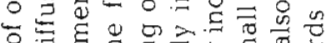

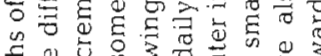

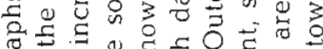

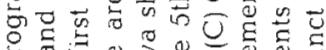

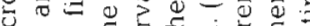

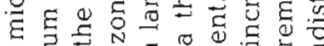
诃

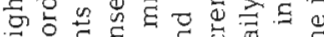

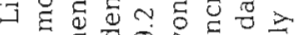
今들

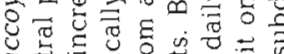

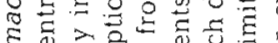
कि

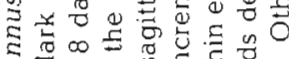

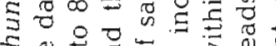
E ن 要医

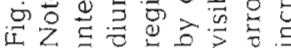



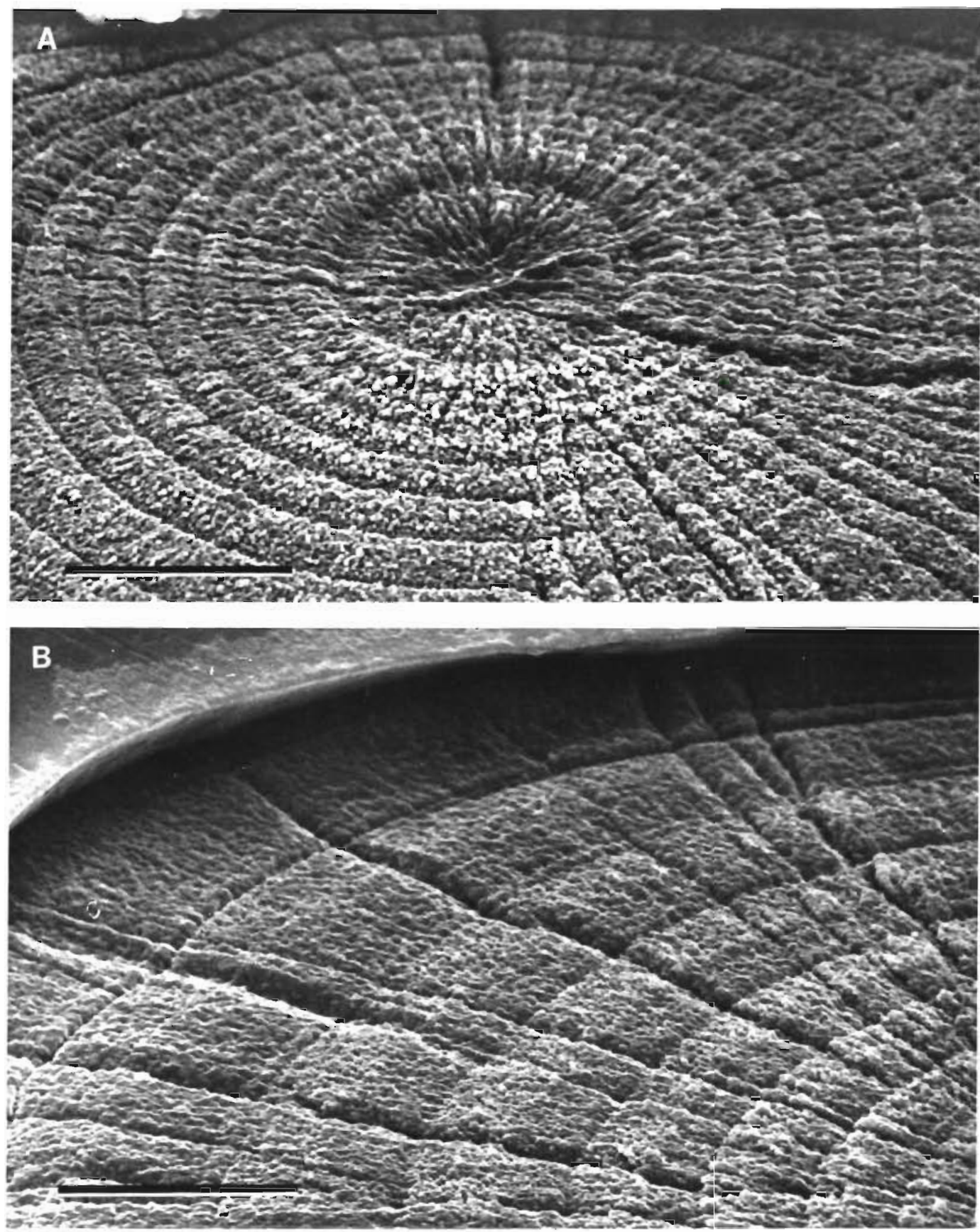

Fig. 3. Thunnus maccoyii. Scanning electron micrographs of otoliths. (A) Central region of sagitta from $9.2 \mathrm{~mm}$ larva shown in Fig. 1B. Note deeply etched area inside distinct daily increments. (B) Outer region of sagitta from $8.0 \mathrm{~mm}$ larva showing distinct daily increments divided into 2 regions of differing etching characteristics. Scale bars $=10 \mu \mathrm{m}$

Measurements were made on sagittae, the largest of the otoliths. Because no difference was found between radii of pairs of sagittae from a subsample of larvae (Paired t-test, $n=40, t=1.357, p>0.1$ ) one sagitta from each pair was randomly selected for measurement. The total radius, radius of the primordium, and radius to each increment were measured; in small larvae, radii were measured along the line of maximum otolith radius; in older larvae, which have elongated otoliths, the maximum radius of the antirostrum was measured. Increments were not clearly visible along the measurement axis in $4 \%$ of otoliths, so they were rejected.

We calculated the index of completion (C) of the marginal increment using the formula of Tanaka et al. (1981): 


$$
\mathrm{C}=\mathrm{W}_{\mathrm{n}} / \mathrm{W}_{\mathrm{n}-1} \times 100
$$

where $W_{n}=$ width of marginal increment, and $W_{n-1}=$ width of the previous complete increment. Specimens were examined randomly and blind with respect to sampling time. Periodicity of increment formation was determined by following the change in the index of completion for sagittae from larvae collected over the $6 \mathrm{~d}$ of random sampling.

Sagittae from 8 specimens between 8.0 and $11.2 \mathrm{~mm}$ $\mathrm{SL}$ were ground and polished on the lateral plane for examination with light and scanning electron microscopes (LM and SEM). Sagittae were mounted in resin blocks and ground to the primordium with 6 and $3 \mu \mathrm{m}$ diamond paste on an automatic lapping machine, then hand polished with $0.1 \mu \mathrm{m}$ aluminium oxide. After light micrography, sagittae were etched with $0.02 \mathrm{~N} \mathrm{HCl}$ for 5 to $10 \mathrm{~s}$, mounted on SEM stubs, and coated with platinum for SEM examination.

\section{RESULTS}

\section{Otolith microstructure}

Sagittae and lapilli of Thunnus maccoyii larvae, when examined by LM, contained bipartite growth increments consisting of an optically transparent and an optically dense zone (Fig. 2A), which we will show to be formed on a daily basis. Innermost increments were 1 to $1.5 \mu \mathrm{m}$ wide, gradually increasing in width towards the otolith edge. This increase was due mostly to the optically transparent zone, while the optically dense zone increased only slightly. In most larvae, the innermost increment was immediately adjacent to a diffuse, optically dense zone with a mean radius of $7.3 \mu \mathrm{m}$ ( $\pm 0.45 \mathrm{SD})$. After the 5 th to 7 th increment in many larvae (particularly the faster growing ones), very narrow, optically dense zones were regularly spaced within each daily increment (Fig. 2B). Thus the daily increment was divided into subdaily units. The increments on otoliths of older larvae contained a distinct subdaily increment and a number of closely spaced, less distinct, subdaily increments; daily increments were more difficult to discern towards the otolith edge of the oldest larvae examined (Fig. 2C) and light and dark areas of increments could reverse under different focusing conditions (Fig. 2C).

Daily increments were very clear when viewed with the SEM (Fig. 3A). The width of the innermost increments were ca 1 to $1.5 \mu \mathrm{m}$, confirming LM observations. The region within the first increment was deeply etched and no structure was visible. Subdaily increments were difficult to discern; apparently they do not etch as deeply as daily increments. The outer increments of larger larvae were well etched, and each increment had an inner, more deeply etched region which appeared darker than the outer. The transition between these 2 zones probably corresponds to the distinct subdaily increment observed in outer increments under LM (Fig. 3B).

\section{Marginal increment analysis}

Larvae examined for marginal increment analysis had between 5 and 13 increments. The period of growth of one complete increment was ca $24 \mathrm{~h}$, indicating that these increments had a daily periodicity (Fig.4). The optically-dense zone of each increment was apparently formed around dusk. The overlap of specimens with almost complete increments and newly developing increments just after dusk was probably due to light diffraction at the edge of the otolith masking the appearance of a new increment in some cases.
Fig. 4. Thunnus maccoyii. Diurnal change in the index of completion ( $C$; see Eq. 1) of the marginal increment of larval sagittae

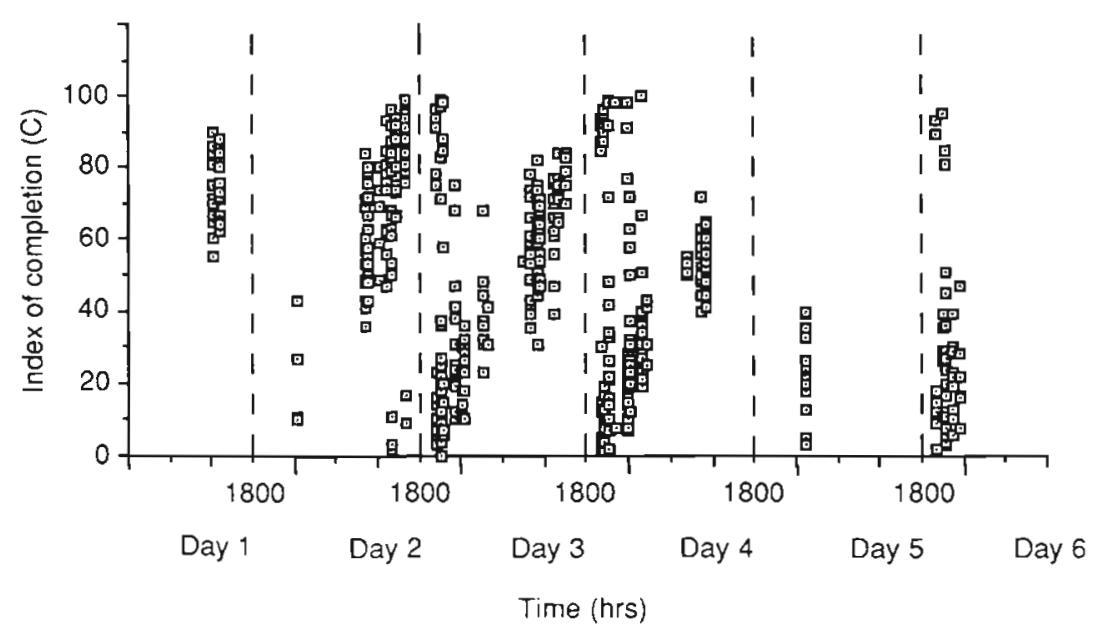




\section{Age distribution}

The age distribution of larvae in random samples is presented in Fig. 5. Days of sampling represent periods from dusk to dusk, i.e. the period of growth of one increment, and the age frequency distribution of the larvae in the station subsamples was used to estimate the age frequency distribution in the total sample, and these frequencies were summed to give the total age frequency distribution for the day. A percentage frequency distribution was then calculated from the age frequency distribution. A distinct cohort of larvae was
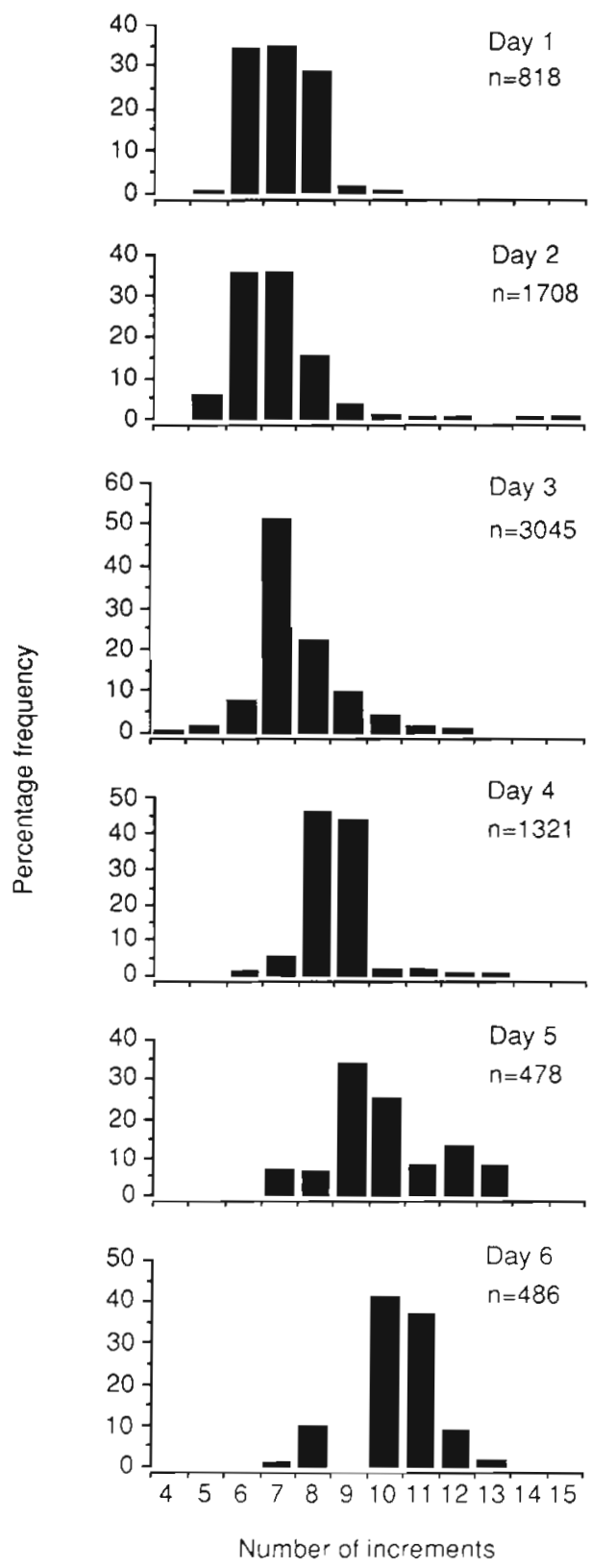

Fig. 5. Thunnus maccoyii. Age distribution of larvae collected from random sampling stations over 6 successive days

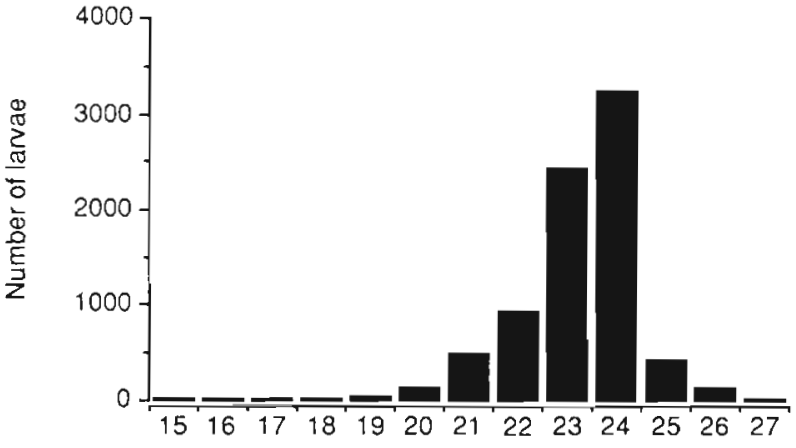

Date of first increment formation (January 1987)

Fig. 6. Thunnus maccoyii. Distribution of estimated dates of first increment formation

present in samples from Days 2 to 6, most larvae apparently originating from a $2 \mathrm{~d}$ spawning event. The progression of one increment per day in this cohort is further evidence that increments are formed daily. This cohort was not represented on Day 1 ; however, most of the samples were out of the main sampling area.

The first increment in otoliths of most larvae were calculated to have formed on 22 and 23 January (Fig. 6). Few larvae collected had first increments formed after these dates, even though they would have been large enough to be collected by our nets. There was a gradual diminution of abundance of larvae with first increments formed in the days preceding this peak.

A range of 4 to 15 increments was counted on otoliths (Fig. 7). Larvae greater than ca $8 \mathrm{~mm}$ SL had almost developed a full complement of fin rays and spines, and showed increasing amounts of juvenile pigment, indicating that they were at an early stage of transformation to the juvenile phase. Larvae with 14 or 15 increments showed an apparent sudden increase in growth rate; however, the sample was too small to ascertain whether this was an actual increase or a sampling artifact.

\section{Growth rate and trajectory}

Determining the growth rate and growth trajectory of the larval population is extremely difficult given the narrow age range and the wide variance in size-at-age (Fig. 7A). Because there were replicate specimens of larvae measured at each age, it was possible to test whether larval length is, in fact, a linear function of age (Sokal \& Rohlf 1981). The ratio of mean square for deviations from regression (2.734) to within groups mean square $(0.201)$ was much greater than one. Therefore length is either a curvilinear function of age, or there is significant heterogeneity around the regression line, or both. A plot of residuals indicates that the variance in length increases with age, violating the 
Fig. 7. Thunnus maccoyii. (A) Relationship between standard length and number of increments on sagittae; (B) relationship between log standard length and number of increments on sagittae
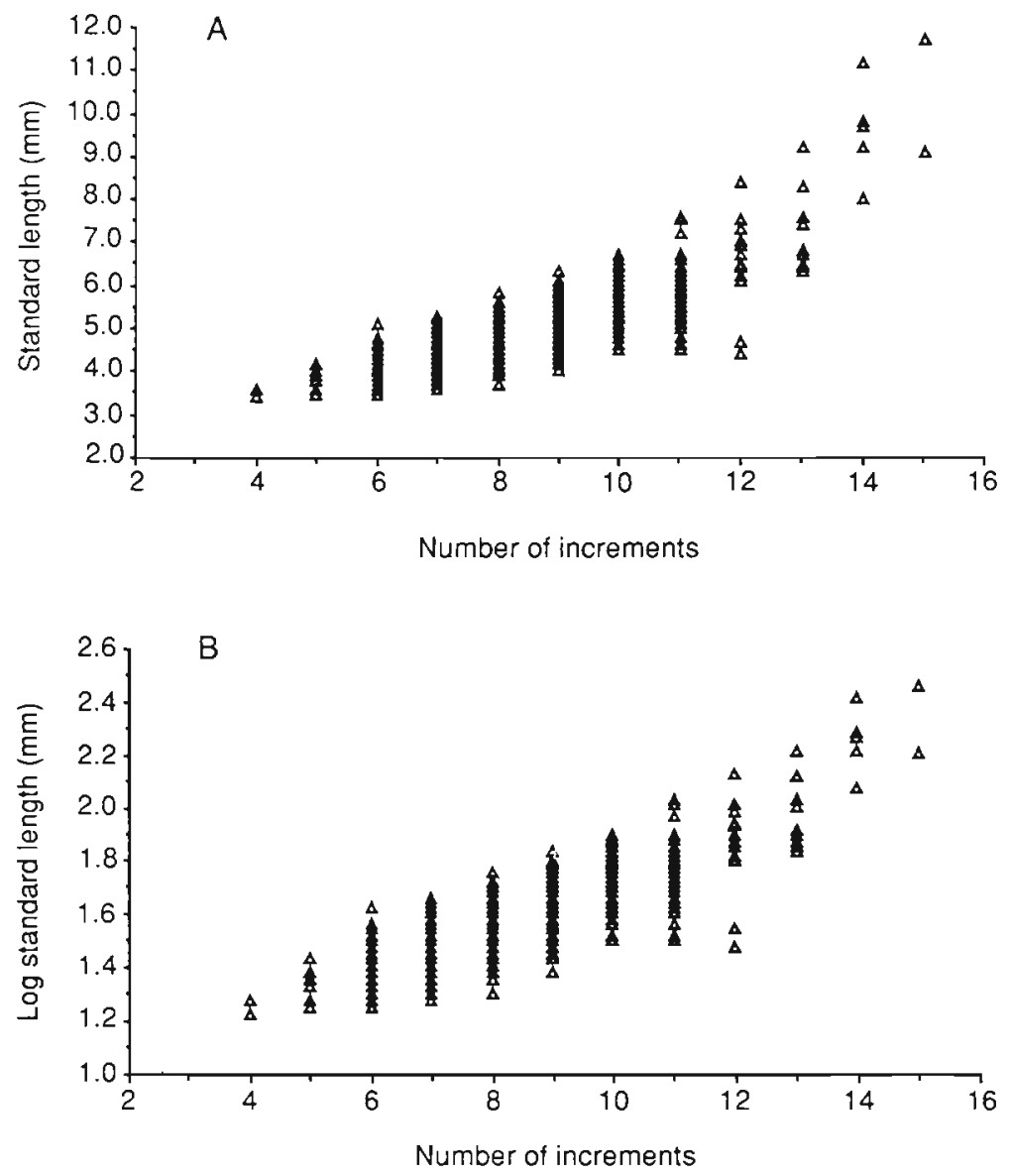

assumption of homogeneous variances. When SL was transformed to logarithms (Fig. $7 \mathrm{~B}$ ), a linear regression also showed a significant deviation from linearity $(\mathrm{F}=3.19)$, and the problem of heteroscedasticity was still apparent in the residual plot. This heterogeneity appears to be partly due to the distribution of larval length being truncated by escapement of small larvae. The size-at-age data is therefore unlikely to be reliable for calculating the trajectory of the growth curve.

An alternative way of examining larval growth is to back-calculate the growth rate of individual larvae. The growth of sagittae is exponential relative to growth in length, although the relationship appears to change in larvae greater than ca $10 \mathrm{~mm} \mathrm{SL} \mathrm{(Fig.} \mathrm{8A).} \mathrm{If} \mathrm{otolith}$ radius (rad) of larvae up to $10 \mathrm{~mm}$ SL is converted to logs, a strong linear relationship with SL is found:

$$
\mathrm{SL}=2.613 \times \ln \mathrm{rad}-3.406, \mathrm{R}^{2}=0.913, \mathrm{n}=580,
$$

and variance is relatively homogeneous (Fig. 8B). The individual growth of larvae from 27 samples with more than 10 larvae was examined. The length of each fish on each day of life was back-calculated by substituting the log-transformed otolith radius to each daily increment into the regression equation. Growth trajectories of all larvae were strongly linear, with a median value for $R^{2}$ of 0.996 (range 0.972 to 1.0 ). The frequency distribution of individual growth rates approximated a normal distribution (Fig. 9), with a mean of $0.32 \mathrm{~mm} \mathrm{~d}^{-1}$ and range of 0.20 to $0.47 \mathrm{~mm} \mathrm{~d}^{-1}$. Growth rate was highly variable, with $95 \%$ confidence limits $(2 \times \mathrm{SD})$ of $0.096 \mathrm{~mm} \mathrm{~d}^{-1}$ or $30 \%$ of the mean. Examples of growth trajectories of individual larvae are given in Fig. 10. Growth trajectories were essentially linear, although slight positive or negative curvilinearity was apparent in some individuals. Nevertheless a linear regression appears to give a good estimate of the average growth rate over the life of an individual larva. The growth trajectory intercept is highly variable, indicating variability in the size and/or the age at which the first increment is formed (Fig. 10).

Unlike the growth trajectories of younger larvae, those of the oldest collected showed an exponential increase in the late larval stage (Fig.11). Given that Fig. 8B suggests that SL is slightly underestimated for largest larvae, growth rates may be more curvilinear than indicated by Fig. 11.

If regression parameters are calculated for the sizeat-age plot using the subset of data from which indi- 

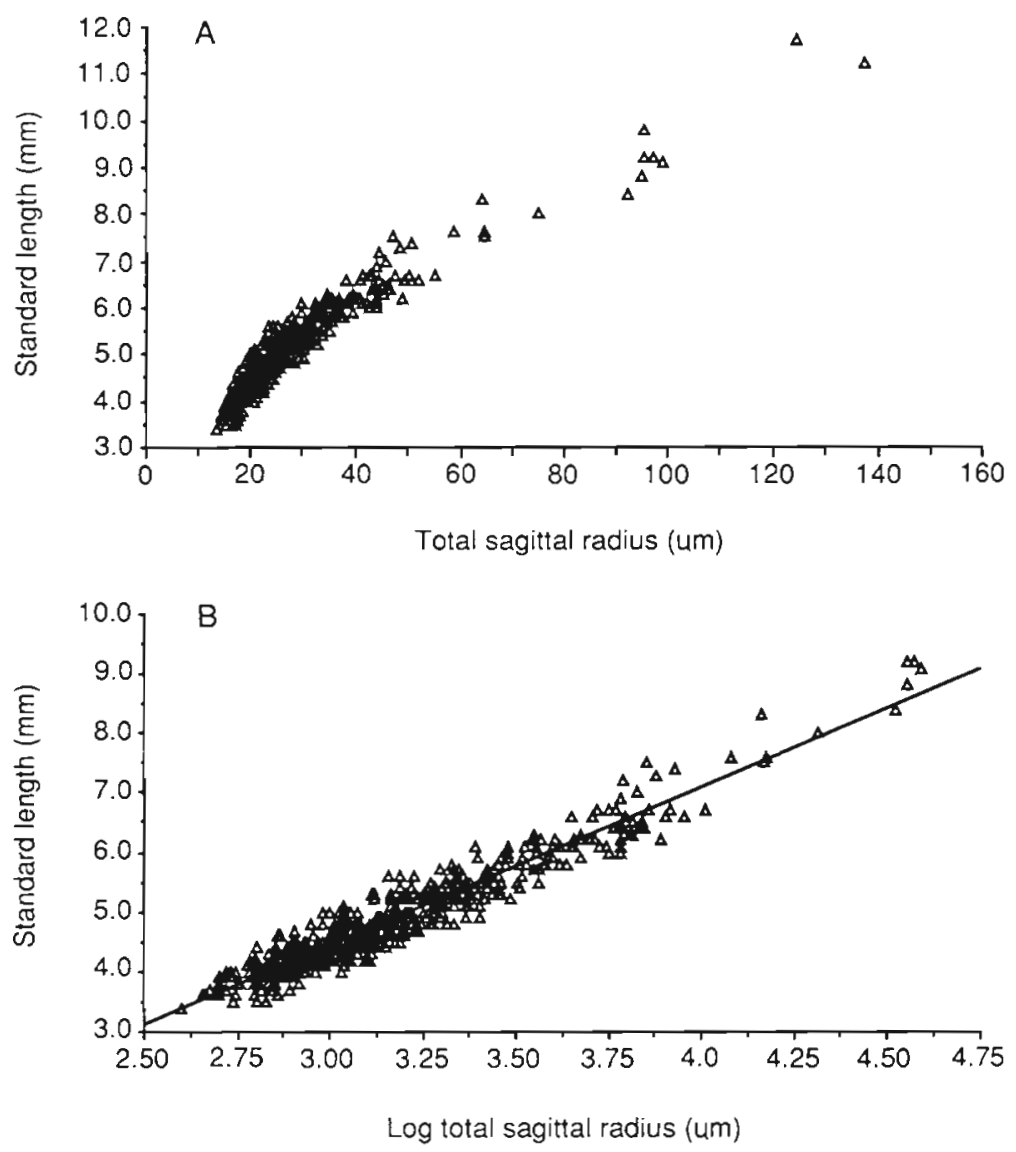

Fig. 8. Thunnus maccoyii. (A) Relationship between standard length and total sagittal radius (B) relationship between standard length and log total sagittal radius together with fitted regression line

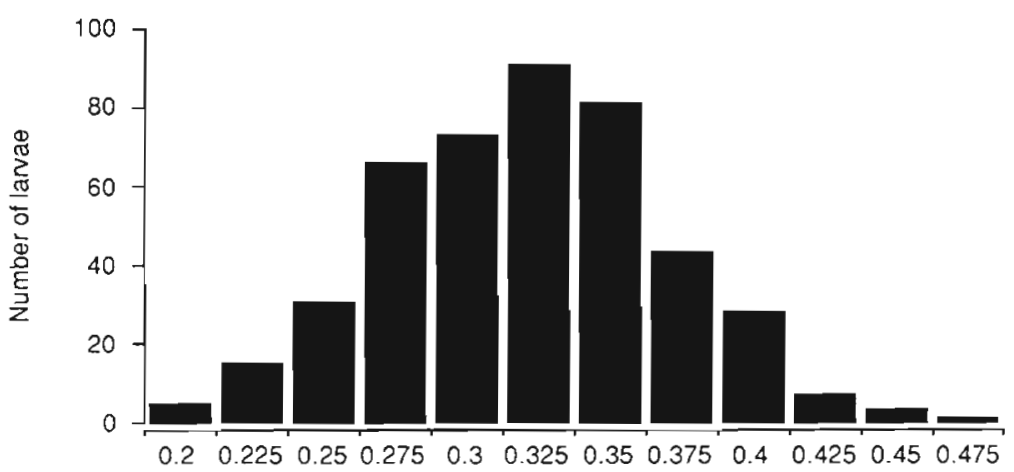

Growth rate mid-point (mm/d)

Fig. 9. Thunnus maccoyii. Frequency distribution of back-calculated growth rates

vidual growth rates were calculated, deviations from linear regression are just significant $(F=1.151)$. Nevertheless, a linear regression line was fitted to the data for comparison with estimates from back-calculation. The regression coefficient was significantly greater than zero $(F=495.71, d f=1,8, p<0.001)$. The equation:

$$
\mathrm{SL}=0.326 \times \text { age }+2.029, \mathrm{R}^{2}=0.563, \mathrm{n}=444
$$

was generated, suggesting an average population growth rate of $0.33 \mathrm{~mm} \mathrm{~d}^{-1}$. This agrees very well with the estimated mean individual growth rate of $0.32 \mathrm{~mm} \mathrm{~d}^{-1}$.

\section{DISCUSSION}

The morphology and microstructure of otoliths of larval Thunnus maccoyii are very similar to those described in Atlantic bluefin tuna $T$ thynnus (Brothers et al. 1983). The increments in otoliths from juvenile $T$. thynnus became thick, optically dense and diffuse beyond ca 15 increments; a similar change was ob- 

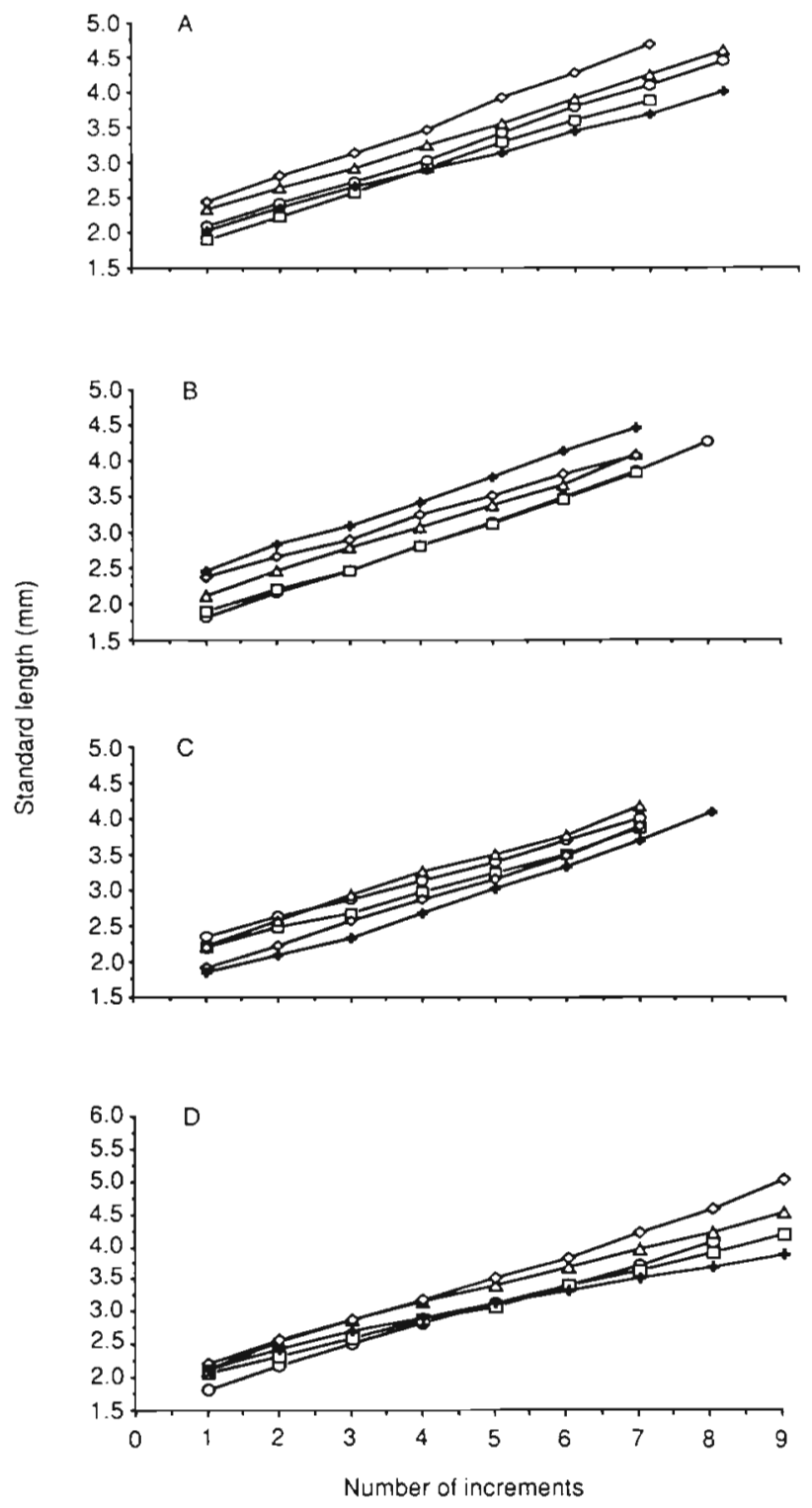

Fig. 10. Thunnus maccoyii. Examples of individual growth trajectories: (A) Stn 252; (B) Stn 272; (C) Stn 291; (D) $\operatorname{Stn} 311$ Each symbol denotes an individual fish served in the outer increments of large $T$. maccoyii larvae with 13 to 15 increments. However, some differences in otolith microstructure were evident in the 2 species. The inner of 2 optically dense layers surrounding the primordium in $T$. thynnus larvae was rarely observed in otoliths of $T$. maccoyii larvae. Furthermore, the optically-dense layer immediately interior to the first clear increment in T. maccoyii had an average diameter of ca $15 \mu \mathrm{m}$ - smaller than the $18 \mu \mathrm{m}$ average for the same dimension in $T$. thynnus larvae. SEM observation confirmed the interpretation of increment structure. Even the narrowest daily increments can be resolved under LM (Campana et al. 1987). Daily increments were well etched; subdaily increments poorly. The change in composition from calcium carbonate to otolin (the deeply etched zone of daily increments; Campana \& Neilson 1985) may not be as great in subdaily increments. Subdaily increments visible under LM may result from some change in the relative contribution of calcium carbonate and otolin, but, the calcium carbonate crystal arrangement and orientation within the calcium carbonate zone may also play a part. The comparatively distinct subdaily increment observed in outer increments of older larvae appears to be a poorly etched ridge of high calcium carbonate concentration. Optically dense layer(s) that can be observed under LM within the first daily increment are not differentially etched and, therefore, are not of typical daily-increment composition.

Analysis of marginal increments of otoliths in Thunnus maccoyii shows that increments in otoliths are formed on a daily basis, which supports Brothers et al. (1983) hypothesis that increments in otoliths of $T$. thynnus are formed daily. Outer increments of $T$. maccoyii larvae were relatively wide $(3$ to $10 \mu \mathrm{m})$ allowing for accurate measurement of marginal increment width. Unlike increments formed during rearing to investigate the periodicity of increment formation (reviewed by Jones 1986), the increments we examined were formed in natural environmental conditions. The results can, therefore, be confidently applied to assigning ages to
Fig. 11. Thunnus maccoyii. Relationship between standard length and number of increments for 3 late-stage larvae

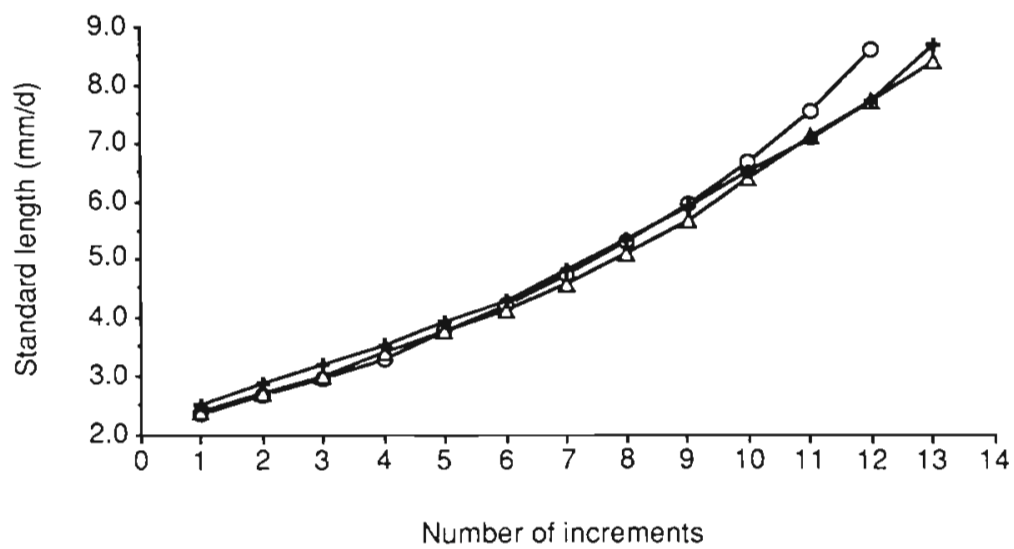

Number of increments 
larvae from the field. Otoliths of the pilchard Sardina pilchardus (Ré 1984), and the pleuronectid flounders Rhombosolea tapirina and Ammotretis rostratus (Jenkins 1987) collected from the sea, also form a dark or discontinuous zone at dusk. These results support Brothers' (1981) hypothesis that the dark, protein-rich portion of the daily increment is formed at night when water temperatures fall. In contrast, the dark increment zone in otoliths from juvenile Tilapia nilotica was formed at the beginning of the light phase in a laboratory light/dark cycle (Tanaka et al. 1981).

Marginal-increment analysis provides no information on when the first increment is formed in Thunnus maccoyii otoliths. Tropical tunas develop rapidiy through the egg and larval stage, typically 1 to $1.5 \mathrm{~d}$ from fertilization to hatching and 2 to $3 \mathrm{~d}$ from fertilization to yolk absorption (Brothers et al. 1983). Initial formation of increments in otoliths may occur prehatching, at hatching, or at first-feeding stages (Jones 1986). Therefore the first increment in otoliths of T. maccoyii would probably have formed 1 to $3 \mathrm{~d}$ after fertilization. In laboratory-reared skipjack tuna Euthynnus pelamis, reared at $26^{\circ} \mathrm{C}$, the first daily increment was formed $1 \mathrm{~d}$ after hatching $(3 \mathrm{~d}$ after fertilization; Radtke 1983). A similar time to first increment formation may also occur in T. maccoyii. Fortunately, the timing of first increment formation is not critical for the present work, which is directed more at growth rates than absolute age.

Most of the larvae in our samples appear to have originated from a major spawning event that either ceased abruptly or shifted in space, although some of the larvae collected on Day 1 of random sampling may have originated from spawning events elsewhere. Some very young larvae which spawned after the major event may have been lost through net escapement, but very few fish eggs of any species were collected in this sampling program, suggesting that spawning had ceased in the area. Larvae from the surface transect undertaken before random sampling had 5 to 6 increments (T, L.O. Davis unpubl.), so were probably also spawned during the major spawning event. Abundances recorded at this earlier stage were extremely high - up to $22 \mathrm{~m}^{-3}$. The peak of spawning would have occurred just before the full moon, but sampling was carried out over too short a period to uncover a relationship between spawning activity and lunar period.

If we assume that the first daily increment in otoliths of Thunnus maccoyii was formed $3 \mathrm{~d}$ after fertilization then the age range in this study was 7 to $18 \mathrm{~d}$. Thus, the duration of the larval phase is brief, probably ca $20 \mathrm{~d}$. Larval drift would, therefore, be of little importance in transporting young T. maccoyi from the spawning grounds. The Leeuwin Current, which is thought to facilitate the transport of young fish to southern Australia, does not exert a significant influence until March/April (Cresswell \& Golding 1980). The satellitetracked drogue used in this study, together with 2 others deployed on this cruise, were never entrained by the Leeuwin Current. Given a development time of ca $20 \mathrm{~d}$ and a spawning period from September to March (Nishikawa et al. 1985), most larvae are likely to complete development close to the site of spawning, and some directed movement of young juveniles may be necessary to entrain them into this current.

The link between the width of the daily increment and the corresponding days' growth has not been studied (Campana \& Neilson 1985), and it cannot be assumed that the back-calculated growth trajectory directly reflects somatic growth. It is likely that otolith growth varies less from day-to-day than somatic growth (Bradford \& Geen 1987). Euthynnus pelamis larvae, for example, continued to form daily increments on otoliths when growth in length had essentially stopped (Radtke 1983). However, back-calculated growth trajectories reflect the longer-term average growth quite well (Wilson \& Larkin 1982, Volk et al. 1984). Because otolith radius and fish length are closely related by a smoothly monotonic curve (Campana \& Neilson 1985), we feel justified in using the backcalculated growth trajectory to estimate the average growth rate over the life of an individual larva. The relationship between otolith radius and SL is probably not constant in space or time (Brothers et al. 1983, Rice et al. 1985), this problem was obviated by using the same larvae for both otolith radius - SL regression and the back-calculation of growth rates. The exponential relationship between otolith radius and SL indicates that this relationship cannot simply be assumed linear (Victor 1986).

The regression method of back-calculation was preferred over the Fraser-Lee method because it cannot be assumed that most of the residual variation around the regression line was natural (Carlander 1981). Shrinkage of larval fish during capture and fixation is highly variable and may be as much as $20 \%$ (Theilacker 1980 , Hay 1981). The relatively constant variance in larval length around the regression line is consistent with the observation that shrinkage decreases with larval size (Theilacker 1980, McGurk 1985). In general, shrinkage during capture and fixation will lead to an underestimate of larvae growth rate.

Although significant regression functions could be fitted to size-at-age plots, heteroscedasticity of variances must cast doubt on the reliability of results. Furthermore, the high variability in size-at-age made it impossible to determine the form of the growth curve; a number of theoretical growth relationships would fit the data equally well. Given the results of back-calcu- 
Table 1. Examples of otolith based estimates of growth rates from field collected larvae. U: unknown

\begin{tabular}{|c|c|c|c|c|}
\hline Species & $\begin{array}{l}\text { Age } \\
\text { (d) }\end{array}$ & $\begin{array}{l}\text { Temp. } \\
\left({ }^{\circ} \mathrm{C}\right)\end{array}$ & $\begin{array}{c}\text { Growth rate } \\
\left(\mathrm{mm} \mathrm{d}^{-1}\right)\end{array}$ & Source \\
\hline \multicolumn{5}{|l|}{ Clupeiformes } \\
\hline Clupea harengus pallasi & $5-30$ & 7 & 0.36 & McGurk (1987) \\
\hline Anchoa mitchilli & $<12$ & 25 & 0.25 & Fives et al. $(1986)$ \\
\hline Brevoortia patronus & $<60$ & $13-21$ & 0.30 & Warlen (1988) \\
\hline Engraulis mordax & $<25$ & $13-16$ & 0.37 & Methot \& Kramer (1979) \\
\hline Sardina pilchardus & $<25$ & 15 & -0.45 & Ré (1984) \\
\hline \multicolumn{5}{|l|}{ Gadiformes } \\
\hline Gadus morhua & $15-30$ & $4-6$ & 0.18 & Bolz \& Lough (1983) \\
\hline Melanogrammus aeglefinus & $5-30$ & $6-8$ & 0.21 & Bolz \& Lough (1983) \\
\hline Theragra chalcogramma & $5-50$ & $5.5-7$ & 0.21 & Kendal et al. (1987) \\
\hline Theragra chalcogramma & $<60$ & $6-8$ & 0.35 & Walline (1985) \\
\hline \multicolumn{5}{|l|}{ Scorpaeniformes } \\
\hline Sebastes spp. & $<80$ & $\mathrm{U}$ & $0.11-0.16$ & Penney \& Evans (1985) \\
\hline \multicolumn{5}{|l|}{ Perciformes } \\
\hline Leiostomus xanthurus & $<15$ & 19 & $\sim 0.35$ & Warlen \& Chester (1985) \\
\hline Trachurus symmetricus & $<25$ & 25 & $\sim 0.16$ & Hewitt et al. (1985) \\
\hline Thallassoma bifasciatum & $<42$ & $\mathrm{U}$ & $0.18-0.26$ & Victor (1986) \\
\hline \multicolumn{5}{|l|}{ Pleuronectiformes } \\
\hline Rhombosolea tapirina & $<25$ & $10-15$ & $0.10-0.23$ & Jenkins (1987) \\
\hline Ammotretis rostratus & $<25$ & $10-15$ & $0.10-0.28$ & Jenkins (1987) \\
\hline Parophrys vetulus & $8-9$ & $12-13$ & 0.32 & Laroche et al. (1982) \\
\hline
\end{tabular}

lation, we can interpret the size-at-age plot as the result of linear growth trajectories diverging from a similar origin. Notwithstanding the problems associated with the size-at-age plot, the average population growth rate estimated from the linear regression agreed very well with the mean individual growth rate.

Although Thunnus maccoyii develop in warm tropical waters, they appear to grow as slowly as many temperate species (Table 1). It is difficult to compare growth in length of morphologically diverse larvae. For example, the elongate morphology of clupeiform larvae may partly account for their growth rates, generally at lower temperatures, being similar to $T$. maccoyii larvae (Table 1). The average growth of $T$. maccoyii larvae was faster than most cold-water species of nonclupeiform larvae, but was similar to early growth of species of this group from warmer water (Table 1). Although relatively slow, linear growth was apparent in T. maccoyii larvae up to ca $8 \mathrm{~mm}$ long, the form of the growth trajectory may change in late stage larvae and early juveniles not sampled in this program. Pacific mackerel Scomber scombrus, also showed slow (ca $0.25 \mathrm{~mm} \mathrm{~d}^{-1}$ ) almost linear, growth over the first 10 to $15 \mathrm{~d}$ until the larvae reached ca 6 to $7 \mathrm{~mm} \mathrm{SL}$, then growth rate increased rapidly through metamorphosis (Hunter \& Kimbrell 1980). It is likely that most T. maccoyii larvae examined in this study were in this slowgrowth phase. The change in morphology of the outer increments in the oldest larvae studied may indicate the onset of the fast-growth phase. This is supported by back-calculation of the growth trajectory of the oldest larvae examined, which showed an exponential increase in growth in the late larval stage. The size-atage plot for the total data set also shows an apparent rapid increase in growth rate of the oldest larvae. Onset of the fast-growth phase in S. japonicus is accompanied by the onset of cannibalism (Hunter \& Kimbrell 1980). This corresponds to the appearance of larval fish in the diet of the oldest T. maccoyii in this study (J. W. Young \& Davis 1990). Otoliths of $T$. thynnus contain a zone of thick, optically dense increments, similar to the outer few increments of the largest $T$. maccoyii larvae examined, which approximately spans increment 15 to 30. This zone may correspond to a period of high growth rate through metamorphosis for these Thunnus species, similar to that observed in S.japonicus. In summary, the fast growth often attributed to young stages of tuna (Brothers et al. 1983) must occur in the late larval - early juvenile stage rather than the larval stage of T. maccoyii.

Acknowledgements. We thank the Master and crew of the FRV 'Soela' for their assistance with field work. We thank P. Bonham, O. Augustine, J. Young and J. May for sorting samples and $P$. Bonham for identifying larvae. S. Wayte advised on statistical analysis and E. Brothers, J. Parslow, W. Kimmerer, M. Kingsford, V. Mawson and F. R. Harden Jones made many useful suggestions for improving the manuscript. This work was carried out while the senior author was the recipient of a CSIRO Postdoctoral Award. 


\section{LITERATURE CITED}

Bolz. G. R., Lough, R. G. (1983). Growth of larval Atlantic cod, Gadus morhua, and haddock, Melanogrammus aeglefinus, on Georges Bank, spring 1981. Fish. Bull. U.S. 81: 827-836

Bradford, M. J., Geen, G. H. (1987). Size and growth of juvenile chinook salmon back-calculated from otolith growth increments. In: Summerfelt, R. C., Hall, G. E. (eds.) The age and growth of fish. The Iowa State University Press, Iowa, p. 453-461

Brothers, E. B. (1981). What can otolith microstructure tell us about daily and subdaily events in the early life history of fish? Rapp. P.-v. Réun. Cons. perm. int. Explor. Mer 178: 393-394

Brothers, E. B., Prince, E. D., Lee, D. W. (1983). Age and growth of young-of-the-year bluefin tuna, Thunnus thynnus, from otolith microstructure. NOAA tech. Rep. NMFS 8: 49-59

Campana, S. E., Neilson, J. D. (1985). Microstructure of fish otoliths. Can. J. Fish. aquat. Sci. 42: 1014-1032

Campana, S. E., Gagné, J. A., Munro, J. (1987). Otolith microstructure of larval herring (Clupea harengus): image or reality? Can. J. Fish. aquat. Sci. 44: 1922-1929

Carlander, K. D. (1981). Caution on the use of the regression method of back-calculating lengths from scale measurements. Fisheries 6: 2-4

Caton, A., Majkowski, J. (1987). Warning issued on global catch limits. Aust. Fish, 46: 22-24

Cresswell, G. R., Golding, T J. (1980). Observations of a south-flowing current on the southeastern Indian Ocean Deep-Sea Res. 27: 449-466

Davis, T. L. O., Jenkins, G. P., Yukinawa, M., Nishikawa, B. (1989). Comparative estimates of abundance of tuna larvae from concurrent sampling by Japanese and Australian research programmes. Fish. Bull. U.S. (in press)

Fives, J. M., Warlen, S. M., Hoss, D. E. (1986). Age and growth of larval bay anchovy, Anchoa mitchilli, from the Newport River estuary, North Carolina. Estuaries 9: 362-367

Hay, D. E. (1981). Effects of capture and fixation on gut contents and body size of Pacific herring larvae. Rapp. P.v. Réun. Cons. perm. int. Explor. Mer 178: 395-400

Hewitt, R. P., Theilacker, G. H., Lo, N. C. H. (1985). Causes of mortality in young jack mackerel. Mar. Ecol. Prog. Ser. 26: $1-10$

Hunter, J. R., Kimbrell, C. A. (1980). Early life history of Pacific mackerel, Scomber japonicus. Fish. Bull. U.S. 78: 89-101

Jenkins, G. P. (1987). Age and growth of co-occurring larvae of two flounder species, Rhombosolea tapirina and Ammotretis rostratus. Mar. Biol. 95: 157-166

Jones, C. (1986). Determining age of larval fish with the otolith increment technique. Fish. Bull. U.S. 84: 91-104

Kendall, A. W. Jr, Clarke, M. E., Yoklavich, M. M., Boehlert, G. W (1987). Distribution, feeding, and growth of larval walleye pollack, Theragra chalcogramma, from Shelikof Strait, Gulf of Alaska. Fish. Bull. U.S. 85: 499-521

Laroche, J. L., Richardson, S. L., Rosenberg, A. A. (1982). Age and growth of a pleuronectid, Parophrys vetulus, during the pelagic larval perıod in Oregon coastal waters. Fish. Bull. U.S. 80: 93-104

McGurk, M. D. (1985). Effects of net capture on the postpreservation morphometry, dry weight, and condition factor of Pacific herring larvae. Trans. Am. Fish. Soc. 114: 348-355

McGurk, M. D. (1987). Age and growth of Pacific herring larvae based on length-frequency analysis and otolith ring number Envir. Biol. Fish. 20: 33-47

Methot, R. D. Jr, Kramer, D. (1979). Growth of northern

This article was submitted to the editor anchovy, Engraulis mordax, larvae in the sea. Fish. Bull U.S. 77: $413-423$

Mosegaard, H., Svedang, H., Tabeman, K. (1988). Uncoupling of somatic and otolith growth rates in Arctic char (Salvelinus alpinus) as an effect of differences in temperature response. Can. J. Fish. aquat. Sci. 45: 1514-1524

Nishikawa, Y (1985). Identification for larvae of three species of genus Thunnus by melanophore patterns. Bull. Far Seas Fish. Res. Lab., Japan 22: 119-129

Nishikawa, Y., Honma, M., Ueyanagi, S., Kikawa, S. (1985). Average distribution of larvae of oceanic species of scombrid fishes, 1956-1981. Contribution Far Seas Fish. Res. Lab., Fish. Agency of Japan 236: 1-99

Pannella, G. (1971). Fish otoliths: daily growth layers and periodical patterns. Science 173: 1124-1127

Penney, R. W., Evans, G. T (1985). Growth histories of larval redfish (Sebastes spp.) on an offshore Atlantic fishing bank determined by otolith increment analysis. Can. J. Fish. aquat. Sci 42: 1452-1464

Radtke, R. L. (1983). Otolith formation and increment deposition in laboratory-reared skipjack tuna, Euthynnus pelamis, larvae. NOAA tech. rep. NMFS 8: 99-103

Ré, P. (1984). Evidence of daily and hourly growth in pilchard larvae based on otolith growth increments, Sardina pilchardus (Walbaum, 1792). Cybium 8: 33-38

Rice, J. A., Crowder, L. B., Binkowski, F. P. (1985). Evaluating otolith analysis for bloater Coregonus hoyi: do otoliths ring true? Trans. Am. Fish. Soc. 114: 532-539

Shingu, C. (1980). Ecology and stock of southern bluefin tuna Tech. Rep. Div. Fish Oceanogr. C.S.I.R.O. 131: 1-79

Sokal, R. R., Rohlf, F. J. (1981). Biometry. W H. Freeman \& Co., New York, p. 859

Tanaka, K., Mugiya, Y., Yamada, J. (1981). Effects of photoperiod and feeding on daily growth patterns in otoliths of juvenile Tilapia nilotica. Fish. Bull. U.S. 79: 459-465

Theilacker, G. H. (1980). Changes in body measurements of larval northern anchovy, Engraulis mordax, and other fishes due to handling and preservation. Fish. Bull. U.S. 78 : 685-692

Victor, B. C. (1986). Delayed metamorphosis with reduced larval growth in a coral reef fish (Thalassoma bifasciatum). Can. J. Fish. aquat. Sci. 43: 1208-1213

Volk, E. C., Wissmar, R. C., Simenstad, C. A., Eggars, D. M. (1984). Relationship between otolith microstructure and the growth of juvenile chum salmon (Onchorhynchus keta) under different prey rations. Can. J. Fish. aquat. Sci. 41: $126-133$

Walline, P. D. (1985). Growth of larval walleye pollack related to domains within the SE Bering Sea. Mar. Ecol. Prog. Ser. 21: 197-203

Warlen, S. M. (1988). Age and growth of larval gulf menhaden, Brevoortia patronus, in the northern Gulf of Mexico. Fish Bull. U.S. 86: 77-90

Warlen, S. M. Chester, A. J. (1985). Age, growth, and distribution of larval spot, Leiostomus xanthurus, off North Carolina. Fish. Bull. U.S. 83: 587-599

Wiison, K. H. Larkin, P. A. (1982). Relatıonship between thickness of daily growth increments in sagittae and change in body weight of sockeye salmon (Oncorhynchus nerka) fry. Can. J. Fish. aquat. Sci. 39: 1335-1339

Young, J. W., Davis, T L. O. (1990) Feeding ecology of larvae of southern bluefin, albacore and skipjack tunas (Pisces: Scombridae) in the eastern Indian Ocean. Mar Ecol. Prog. Ser. 61. 17-29

Manuscript first received: May 23, 1989

Revised version accepted: December 6, 1989 